\title{
Identifikasi Deformasi Tektonik Aktif Berdasarkan Ekstraksi Kelurusan Morfologi dan Seismisitas di Sukabumi, Jawa Barat
}

\section{Identification of Active Tectonic Deformation based on Morphology Lineaments Extraction and Seismicity in Sukabumi, West Java}

\author{
Rizqi Muhammad Mahbub ${ }^{1 *}$, Candra Ragil ${ }^{2}$ \\ ${ }^{1}$ Program Studi Teknik Geologi, FTM, Institut Teknologi Nasional Yogyakarta \\ ${ }^{2}$ Program Studi Perencanaan Wilayah dan Kota, FTSP, Institut Teknologi Nasional Yogyakarta \\ Jl. Babarsari, Caturtunggal, Depok, Sleman, Daerah Istimewa Yogyakarta, Indonesia, 55281 \\ *E-mail: rizqimahbub@itny.ac.id
}

Naskah diterima: 5 Desember 2020, direvisi: 22 April 2021, disetujui: 17 Mei 2021

DOI: 10.17146/eksplorium.2021.42.1.6139

\begin{abstract}
ABSTRAK
Pusat gempa bumi di Sukabumi telah membentuk deformasi bawah permukaan dan kini terekam juga di permukaan. Hal itu termanifestasi melalui geomorfologi kelurusan gawir dan sungai. Ekstraksi kelurusankelurusan akibat deformasi geologi tersebut dapat digunakan untuk mengidentifikasi deformasi tektonik aktifnya. Tujuan penelitian ini adalah untuk mengetahui hubungan antara struktur sesar aktif dengan arah dominan kelurusan di daerah penelitian. Metode Edge Enhancing Filtering digunakan untuk menginterpretasi kelurusan secara manual dan semi-otomatis. Data geospasial kelurusan diekstraksi menggunakan formula Sastratenaya untuk mengetahui kronologi kelurusan yang terbentuk. Hasil analisis menggunakan formula Sastratenaya menunjukkan kelurusan-kelurusan yang terekam melalui olah data peta DEM, yaitu segmen 1 berarah $\mathrm{N} 315^{\circ} \mathrm{E}$ dan segmen 2 berarah $\mathrm{N} 10^{\circ} \mathrm{E}$ yang diinterpretasikan sebagai hasil reaktivasi sesar. Hal ini dapat diinterpretasikan bahwa Sesar Cimandiri, yang merupakan sesar aktif dengan pergerakan oblique-slip sinistral N88 E $/ 85^{\circ}$ rake $33^{\circ}$, memengaruhi arah dua segmen kelurusan di daerah penelitian wilayah Sukabumi, Jawa Barat.
\end{abstract}

Kata kunci: Sukabumi, kelurusan, formula Sastratenaya, citra DEM, sesar aktif

\begin{abstract}
The epicenter of the earthquake in Sukabumi has formed subsurface deformation which is now also recorded on the surface area. This is manifested through the geomorphology of the scarp and river lineaments. Extraction of lineaments produced by geological deformation can be used to identify its active tectonic deformation. The research objective is to determine the relationship between the active fault structure and the dominant direction of lineaments in the study area. The Edge Enhancing Filtering method is used to interpret lineaments manually and semi-automatically. The lineament geospatial data was extracted using the Sastratenaya formula to determine the chronology of the lineaments formed. The Sastratenaya formula results showed the lineaments recorded by DEM images data processing, the first segment direction is $N 315^{\circ} \mathrm{E}$ and the second is $N 10^{\circ} \mathrm{E}$, both are interpreted as the result of fault reactivation. It can be interpreted that the Cimandiri Fault, which is an active fault that has an $N 88^{\circ} \mathrm{E} / 85^{\circ}$ rake $33^{\circ}$ sinistral oblique-slip fault movement, affects the lineaments direction of two segments in the research area of Sukabumi, West Java.
\end{abstract}

Keywords: Sukabumi, lineament, Satratenaya formula, DEM image, active fault 


\section{PENDAHULUAN}

Jawa Barat merupakan salah satu wilayah di Indonesia yang mengalami deformasi aktif hingga saat ini. Aktivitas tektonik lempeng menghasilkan sesar aktif, salah satunya Sesar Cimandiri yang berlokasi di daerah padat penduduk seperti Sukabumi dan Bandung. Sesar Cimandiri sebagai zona deformasi terdiri atas sejumlah sesar dan lipatan [1]. Sistem Sesar Cimandiri meningkatkan bahaya gempa bumi di kota Sukabumi yang padat penduduk [2]. Wilayah persebaran gempa bumi terbilang cukup merata di Sukabumi yang memiliki jumlah episenter dengan kriteria momen magnitudo gempa dangkal $\mathrm{M}$ $>3$ [3]. Pola seismisitas menunjukkan beberapa kelompok sesar aktif di Jawa Barat dengan pergerakan sesar mendatar sinistral, yaitu Sesar Cimandiri [4]. Penelitian ini penting dilakukan untuk mengidentifikasi deformasi geologi yang berhubungan dengan tektonik aktif. Peta persebaran sumber gempa di daerah penelitian dapat dilihat pada Gambar 1.

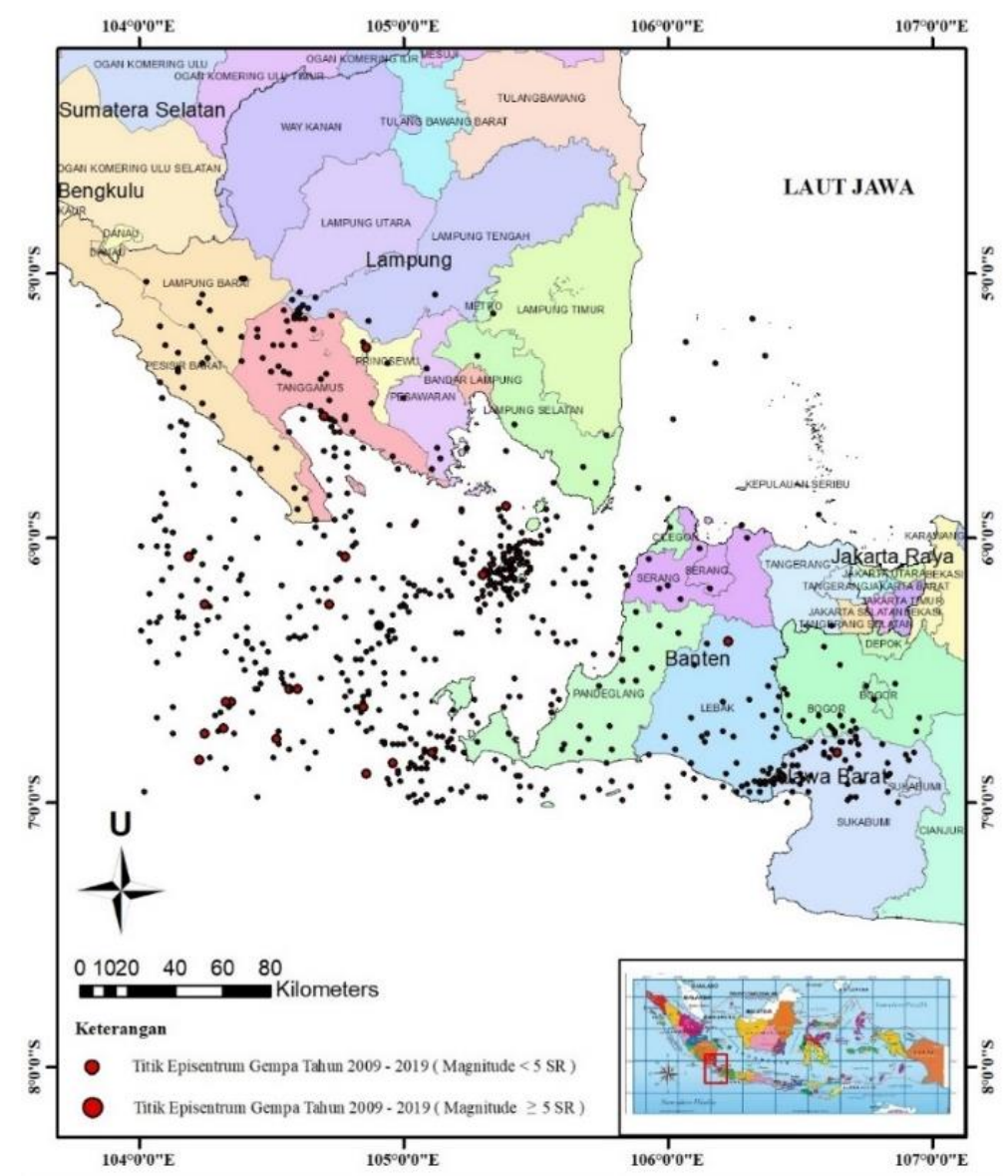

Gambar 1. Peta administrasi sebaran sumber gempa periode tahun 2009-2019 di daerah penelitian dan sekitarnya.

Daerah penelitian di Sukabumi secara umum didominasi sesar reaktivasi berarah barat laut-tenggara yang dikontrol oleh tektonik kompresi aktif di selatan Jawa. Pembentukan sesar-sesar ini terjadi pada Kala Miosen hingga Resen. Berdasarkan data Digital Elevasi Model (DEM) dan Peta
Geologi Regional Jawa Barat terdapat banyak kelurusan di batuan Tersier. Tektonik kompresi mengaktifkan sesar-sesar utama dengan perpindahan dan pergeseran pada segmen-segmen kelurusan morfologi.

$$
\text { Analisis kelurusan morfologi }
$$
menggunakan citra DEM dilakukan untuk 
membantu identifikasi morfologi yang dipengaruhi oleh tektonik aktif. Tingkat kesamaan dalam orientasi kelurusan, sistem drainase, dan arah struktur bawah permukaan menunjukkan intensitas kontrol struktur yang mendasari fitur geomorfologi permukaan [5]. Interpretasi kelurusan geologi menggunakan penginderaan jauh dan citra DEM memudahkan proses analisis tektonik dan pergerakan lempeng [6]. Kronologi pembentukan kelurusan topografi diklasifikasikan dengan formula Sastratenaya [7]. Densitas kelurusan yang tinggi disebabkan oleh deformasi tektonik [8]. Bentuk yang pipih paralel serta memiliki orientasi di antara topografi tinggi dan rendah menunjukkan daerah potensi struktur [9]. Produk seismisitas yang dicirikan oleh tipe mekanisme sumber gempa di laut selatan Jawa adalah sesar naik [10].

Tujuan dari penelitian ini adalah untuk mengetahui hubungan antara sesar aktif dengan arah dominan kelurusan di daerah penelitian. Hasil penelitian ini diharapkan dapat digunakan sebagai salah satu acuan dalam menganalisis sesar-sesar aktif menggunakan metode serupa di daerah lain yang memiliki kondisi geologi serupa serta menjadi sebuah penelitian yang berkelanjutan.

\section{METODOLOGI}

Garis-garis yang terlihat jelas atau samar dari piksel dalam citra DEM merupakan kelurusan topografi. Beberapa kelurusan tersebut antara lain adalah sesar, lipatan, dan rekahan yang mengalami pergeseran. Sejumlah peneliti menginterpretasi algoritma seperti jejak segmen, analisis hidrologi, serta garis lembah dan punggungan berdasarkan variasi arah dan nilai piksel [6].

Analisis kelurusan pada dasarnya adalah mengekstraksi gambar menggunakan media citra satelit. Variasi interval panjang gelombang adalah parameter yang dapat membedakan kelurusan dengan baik. Pengolahan data citra dilakukan dengan menajamkan gambar untuk mendapatkan informasi. Ekstraksi kelurusan secara manual dapat dilakukan dengan model citra hillslope. Beberapa metode yang dapat digunakan dalam mengekstraksi kelurusan, yaitu Edge Enhancing Filtering, Principal Component Analysis (PCA), Spectral Rationing, dan Color Composite [11], [12]. Metode yang digunakan untuk penelitian ini adalah Edge Enhancing Filtering yang kemudian dikombinasikan dengan model citra hillslope untuk menginterpretasi kelurusan secara manual dan semiotomatis dengan perangkat lunak Geomatica. Citra DEM ditingkatkan kualitasnya menggunakan model citra hillslope. Metode ini dilakukan untuk mempertajam unsur topografi seperti kelurusan punggungan dan lembahan dengan sudut penyinaran $45^{\circ}$ dan arah azimuth: $45^{\circ}$, $90^{\circ}, 135^{\circ}, 180^{\circ}, 225^{\circ}, 270^{\circ}, 315^{\circ}$, dan $360^{\circ}$. Pengamatan visual dilakukan untuk menentukan arah kelurusan dominan. Derajat azimuth penyinaran yang berbeda-beda memudahkan pengamatan pola kelurusan yang dominan secara konsisten. Metode densitas kelurusan dapat digunakan untuk kelurusan rapat yang teridentifikasi sebagai sesar permukaan [13].

Kelurusan adalah sebuah pola yang secara visual pada model dan peta terekspresikan sebagai garis dan azimuth di permukaan bumi dan dapat menunjukkan fenomena di bawah permukaan bumi. Pada tahap pengolahan data menggunakan Global Mapper, pembuatan batas daerah disesuaikan dengan kebutuhan penelitian. Tahap ekstraksi kelurusan pada citra yang telah diolah menambah informasi mengenai arah dan panjang kelurusan. Kombinasi kelurusan 
secara otomatis dengan data geospasial (panjang, densitas, dan arah) dapat memperbarui tataan tektonik dan menentukan zona hancuran [14]. Metode berikutnya yang digunakan adalah pemakaian hasil ekstraksi kelurusan topografi dengan memisahkan kelurusan berdasarkan jumlah kelurusan yang dominan. Persamaan formula Sastratenaya [12], [7] adalah sebagai berikut:

$$
Q=\frac{\text { Panjang Kumulatif }(\%)}{\text { Frekuensi Relatif }(\%)}=\frac{P K}{F R}
$$

Penggambaran kelurusan topografi punggungan dan lembahan bertujuan untuk mengetahui hubungan struktur geologi yang berkembang di daerah penelitian. Dalam penentuan kelas arah, apabila $\mathrm{Q}<1$ maka sistem kelurusan relatif tua, Q $>1$ merupakan sistem kelurusan yang relatif muda, sedangkan nilai $Q$ antara 0,9-1,0 adalah kelurusan yang dominan terbentuk karena reaktivasi sesar.

Tahap berikutnya adalah pengukuran kegempaan di wilayah Sukabumi dengan mengamati hasil analisis mekanisme sumber gempa yang pernah ada. Pengukuran bidang nodul menggambarkan arah pergerakan hanging wall. Pergerakan hanging wall dengan rake $0-10^{\circ}$ dan $170-180^{\circ}$ diinterpretasikan sebagai gejala sesar mendatar sinistral atau dekstral.

Seismisitas regional dapat dihubungkan dengan pengukuran deformasi seperti sesar atau kelurusan struktur. Kebanyakan hancuran gempa bumi terjadi di zona sesar. Penelitian yang umum dilakukan adalah menemukan kelurusan dari pemetaan penginderaan jauh [15]. Gempa tektonik yang terekam oleh BMKG sejak 2009 hingga 2019 digunakan untuk menganalisis kondisi tektonik akif di sekita Selat Sunda. Peta kelurusan merupakan hasil integrasi antara struktur dengan informasi geologi bentang alam. Efek kelurusan pada daerah gempa bumi telah dianalisis menggunakan ekstraksi dan dimensi fraktal. Hasil pengukuran data sumber gempa yang dikaitkan dengan deformasi akibat aktivitas tektonik pada daerah penelitian dibandingkan dengan model kelurusan yang telah diinterpretasi. Analisis tersebut digunakan untuk mengetahui morfologi yang masih dikontrol aktivitas tektonik hingga saat ini.

\section{HASIL DAN PEMBAHASAN}

Kelurusan-kelurusan topografi di daerah penelitian dikategorikan berdasarkan hasil delineasi pada Digital Elevation Model (DEM) dan data geologi regional. Kelompok kelurusan di sebagian wilayah Jawa diinterpretasi sebagai manifestasi sistem struktur sesar. Kelompok ini disebut sebagai segmen-segmen kelurusan. Jawa bagian barat memiliki enam segmen yang terbentuk dan dipengaruhi aktivitas tektonik. Keenam segmen tersebut memiliki arah kelurusan yang cenderung berbeda. Faktor yang memengaruhinya adalah geometri dan mekanisme sesar. Geometri yang diamati antara lain panjang kelurusan, orientasi, dan jumlah kelurusan sedangkan mekanisme berkaitan dengan sejarah struktur, termasuk deformasi tektonik dan analisis pergerakan. Setiap segmen sangat berkaitan dengan pembentukan kelurusan yang dipengaruhi oleh aktivitas tektonik.

\section{Distribusi Kelurusan dan Analisis Spasial Kelurusan}

Hasil olahan raster menunjukkan bahwa kelurusan yang mendominasi Pulau Jawa berada di bagian selatan dan tengah sedangkan Pulau Sumatera hanya di bagian 
barat (Gambar 2). Kelurusan di Pulau Jawa digunakan sebagai dataset kemudian dihubungkan dengan fase deformasi tektonik. Kelurusan tersebut selanjutnya dikelompokkan menjadi enam segmen di Jawa bagian Barat berdasarkan peta geologi regional (Tabel 1). Keenam segmen ini diinterpretasikan berkorelasi dengan mekanisme gempa hingga saat ini.

Keberadaan sistem sesar aktif di Cimandiri, Sukabumi yang berarah timur laut-barat daya dan keberadaan episentrum di daerah ini mengakibatkan berkembangnya berbagai kelurusan di sepanjang perbatasan segmen. Oleh karena itu, wilayah ini dipilih untuk penelitian. Fitur kelurusan seperti rekahan, bidang sesar, dan bidang perlapisan terdapat di daerah penelitian.

Analisis spasial geometri menunjukkan bahwa parameter seperti jumlah, panjang, dan kerapatan kelurusan berpengaruh signifikan terhadap pembentukan dan distribusi kelurusan di setiap segmen. Pendekatan penginderaan jauh yang dikembangkan dalam penelitian ini diterapkan untuk menafsirkan kelurusan dan mengevaluasi zona sesar aktif.

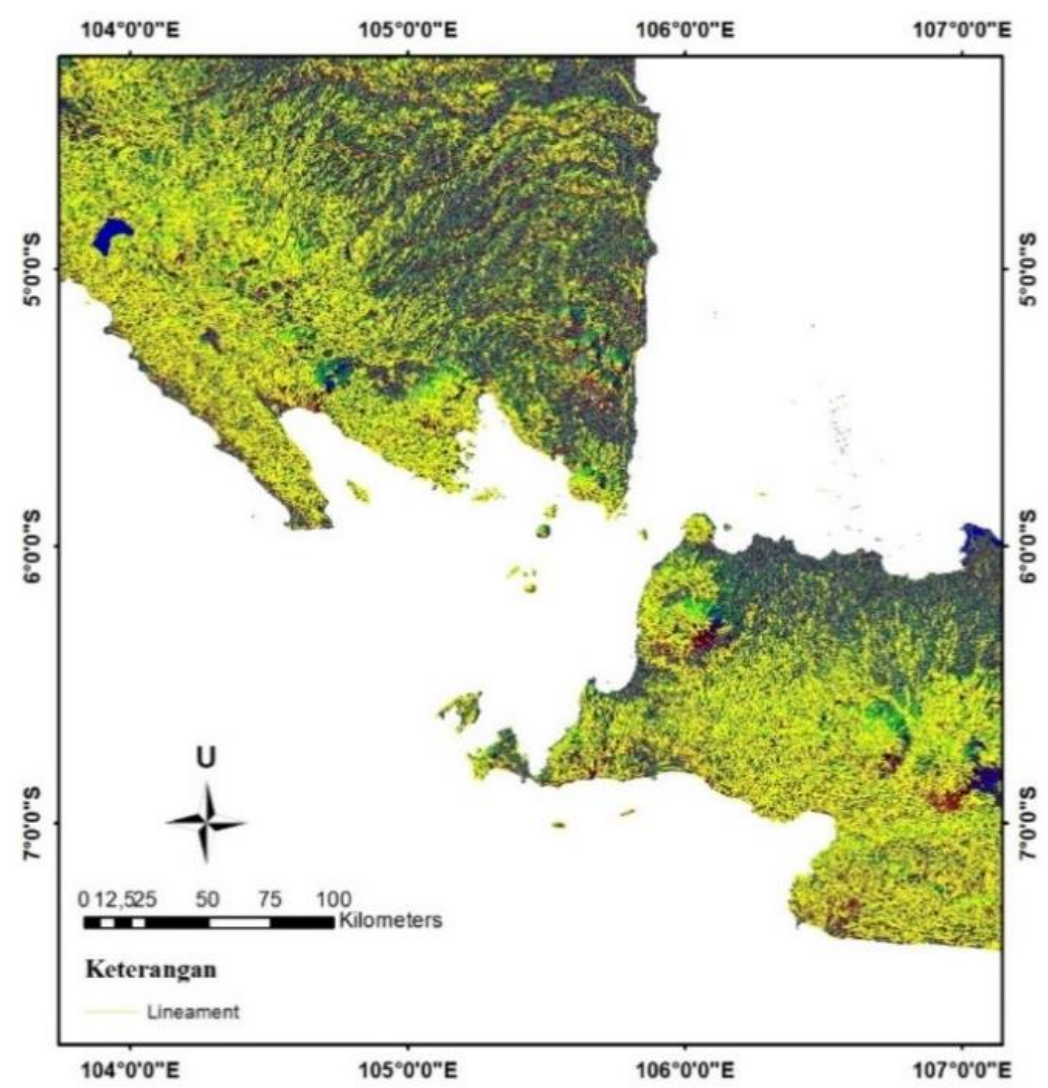

Gambar 2. Delineasi kelurusan topografi pada model hillslope.

Tabel 1. Tabulasi kelurusan topografi.

\begin{tabular}{cccccc}
\hline Segmen & $\begin{array}{c}\text { Panjang Kumulatif } \\
(\mathrm{PK})\end{array}$ & $\begin{array}{c}\text { Frekuensi Relatif } \\
(\mathrm{FR})\end{array}$ & $\mathrm{Q}=\mathrm{PK} / \mathrm{FR}$ & $\begin{array}{c}\text { Tren umum } \\
\left(\mathrm{N} . .^{\circ} \mathrm{E}\right)\end{array}$ & $\begin{array}{c}\text { Keterangan } \\
\text { Tren }(\operatorname{arah})\end{array}$ \\
\hline 1 & 4,1 & 4,3 & 0,953488372 & $90-124$ & Barat laut-Tenggara \\
2 & 4,14 & 4,2 & 0,985714286 & $169-190$ & Utara-Selatan \\
3 & 6,23 & 6,33 & 0,984202212 & $167-190$ & Utara-Selatan \\
4 & 5,24 & 4,91 & 1,067209776 & $130-150$ & Barat laut-Tenggara \\
5 & 4,71 & 4,49 & 1,048997773 & $75-90$ & Barat-Timur \\
6 & 4,21 & 4,01 & 1,049875312 & $164-190$ & Utara-Selatan \\
\hline
\end{tabular}




\section{Densitas Kelurusan}

Analisis kerapatan kelurusan dilakukan pada setiap luas wilayah $1 \mathrm{~km}^{2}$ pada citra DEM model hillslope. Nilai densitas yang didapatkan dari pengelompokkan kelurusan dapat dikategorikan dalam kelas lemah hingga kuat. Hasil penelitian menunjukkan bahwa konsentrasi kelurusan tertinggi terdapat di Sukabumi, yang bertepatan dengan Sesar Cimandiri yang berarah timur laut-barat daya. Densitas kelurusan menunjukkan kerapatan sebesar 6,741-7,437 $\mathrm{km} / \mathrm{km}^{2}$ pada perbatasan segmen ke-1 dan ke2. Bagian utara dari segmen ke-1 merupakan zona lemah yang dipengaruhi oleh aktivitas tektonik Resen, dengan pola kelurusan dominannya adalah barat laut-tenggara $\left(\mathrm{N} 315^{\circ} \mathrm{E}\right)$ dan barat-timur $\left(\mathrm{N} 90^{\circ} \mathrm{E}-\mathrm{N} 110^{\circ} \mathrm{E}\right)$ (Gambar 3). Segmen ke-2 yang memiliki orientasi kelurusan $\mathrm{N} 10^{\circ} \mathrm{E}$ merupakan zona lemah yang berarah utara-selatan dan diinterpretasi sebagai akibat sesar normal dengan gaya utama dari selatan.

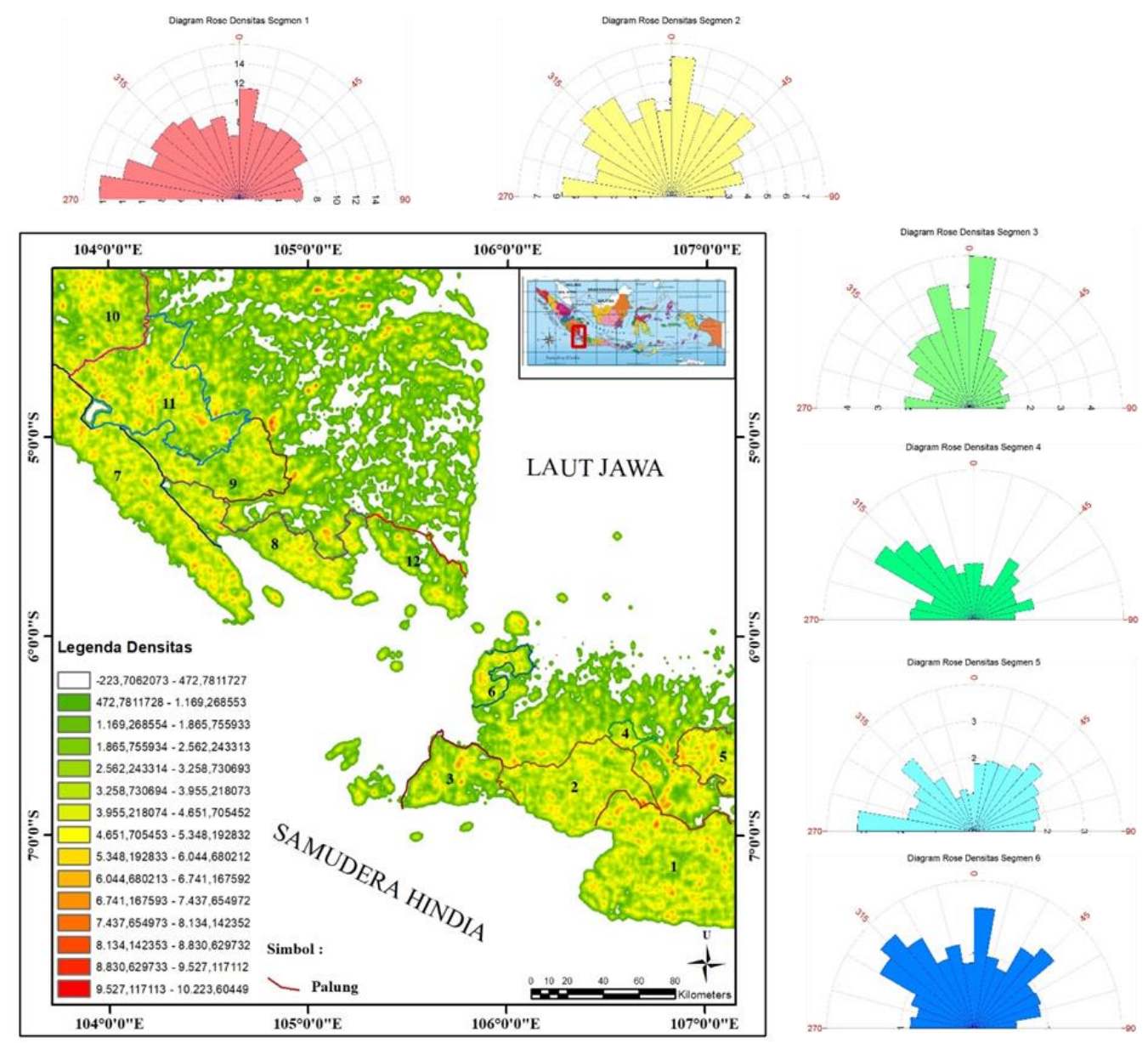

Gambar 3. Peta densitas kelurusan wilayah Sukabumi dan sekitarnya.

Pola kelurusan ditentukan berdasarkan unsur morfologi dan segmen-segmen yang dianalisis dari hasil penginderaan jauh. Hasil analisis menunjukkan tiga pola kelurusan pada setiap segmen, yaitu barat laut-tenggara, utara-selatan, dan barat-timur. Pemetaan geologi regional yang telah dilakukan menunjukkan adanya kesamaan pola orientasi [16]. Hasil penelitian memiliki kemiripan dengan model analog sistem sesar mendatar yang dipengaruhi stress utama dari arah N10 E. Gambaran geologi setempat 
menunjukkan bahwa segmen 1 dan 2 dua episenter yang berada di zona Sesar dipengaruhi oleh gaya berpasangan dan Cimandiri. Episenter pertama berada di dikontrol oleh sesar aktif Cimandiri. kedalaman $10 \mathrm{~km}$ dengan bidang sesar Pengamatan unsur struktur di kedua segmen $\mathrm{N} 90^{\circ} \mathrm{E} / 90^{\circ}$ rake $0^{\circ}$ dan episenter kedua berada menunjukkan komponen Sesar Cimandiri yang bergerak sinistral.

\section{Mekanisme Sumber Gempa}

Pola struktur geologi yang berkembang di wilayah Sukabumi bagian selatan memiliki pola tegak lurus terhadap subduksi yang berarah barat-timur. Pada tahun 2018 terdapat di kedalaman yang sama dengan bidang sesar $\mathrm{N} 88^{\circ} \mathrm{E} / 85^{\circ}$ rake $33^{\circ}$ bergerak turun. Kedua data gempa ini sangat berkaitan dengan pergerakan Sesar Cimandiri yang mengalami reaktivasi. Peta gempa dan hasil analisis gerakan sesar di sekitar Selat Sunda dapat dilihat pada Gambar 4.

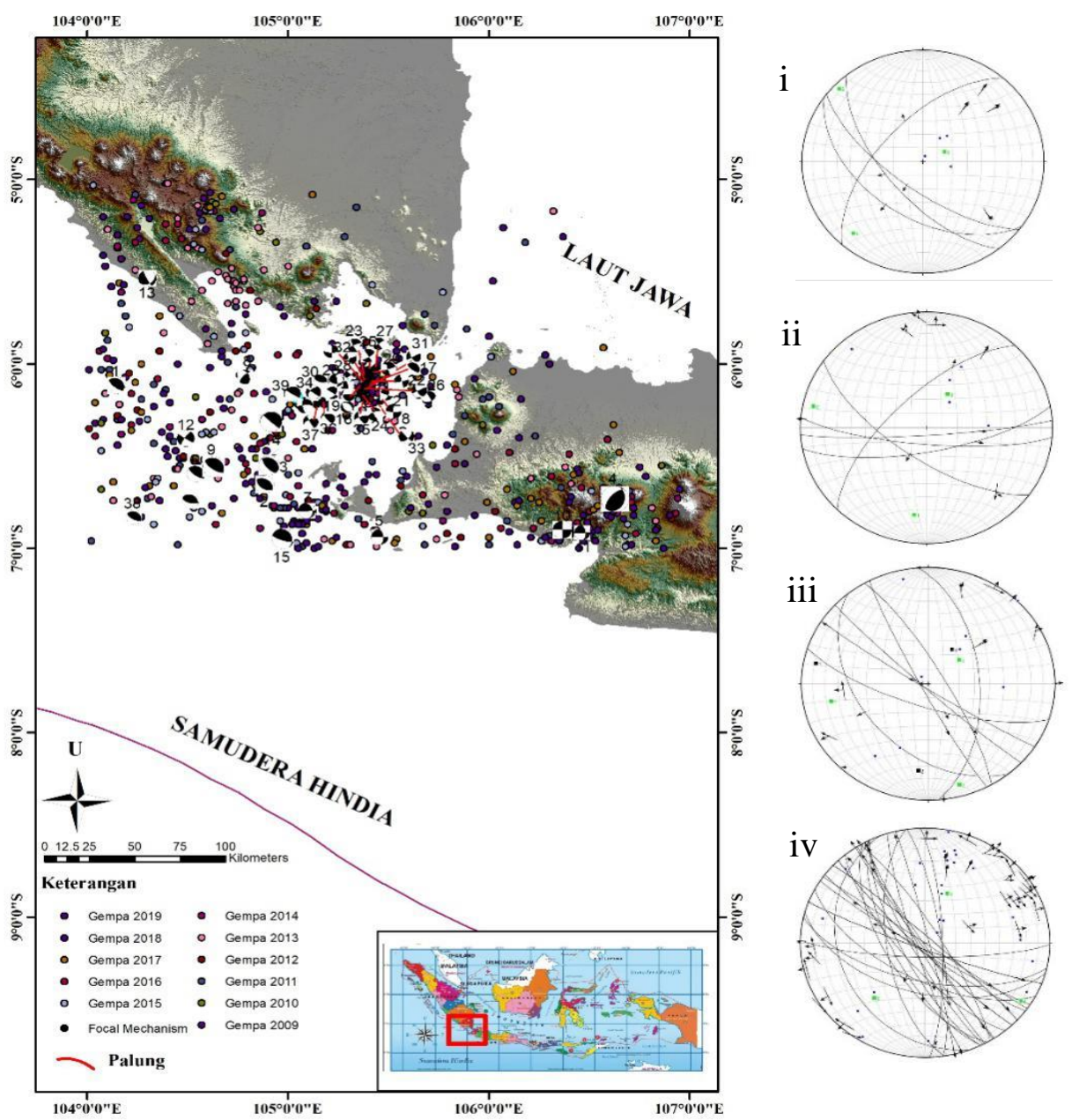

Gambar 4. Peta gempa yang dipusatkan di Selat Sunda dan sekitarnya tahun 2009-2019. Analisis gerakan hanging wall: (i) tahun 2016; (ii) tahun 2017; (iii) tahun 2018; (iv) tahun 2019. Berdasarkan pola gerakan hanging wall ke 4, tahun ini kelurusan didominasi oleh bidang sesar berarah barat laut-tenggara.

\section{KESIMPULAN}

Nilai kerapatan kelurusan tertinggi $6,741-7,437 \mathrm{~km} / \mathrm{km}^{2}$ berkaitan dengan evolusi morfologi setelah deformasi tektonik.
Mekanisme pergerakan oblique-slip sinistral $\mathrm{N} 88^{\circ} \mathrm{E} / 85^{\circ}$ rake $33^{\circ}$ yang berkorelasi dengan sesar aktif Cimandiri merupakan bukti aktivitas tektonik Resen. Sistem kelurusan 
topografi pada segmen 1 dan 2 yang berturutturut berarah $\mathrm{N} 315^{\circ} \mathrm{E}$ dan $\mathrm{N} 10^{\circ} \mathrm{E}$ merupakan hasil reaktivasi Sesar Cimandiri sedangkan segmen ke-4, 5, dan 6 merupakan sistem kelurusan yang lebih muda berdasarkan formula Sastratenaya.

\section{UCAPAN TERIMA KASIH}

Penulis berterima kasih kepada Kementerian Pendidikan dan Kebudayaan atas pendanaan hibah untuk penelitian ini. Selain itu, penulis juga berterima kasih atas dukungan dari manajemen ITNY, khususnya Dr. Ir. Ircham, M.T. selaku Rektor dan Dr. Hill Gendoet Hartono yang telah memberi masukan dan diskusi.

\section{DAFTAR PUSTAKA}

[1] G. I. Marliyani, J. R. Arrowsmith, dan K. X. Whipple, "Characterization of Slow Slip Rate Faults in Humid Areas: Cimandiri Fault Zone, Indonesia," J. Geophys. Res. Earth Surf., vol. 121, no. 12, hal. 2287-2308, 2016, doi: 10.1002/2016JF003846.

[2] E. Gunawan dan S. Widiyantoro, "Active Tectonic Deformation in Java, Indonesia Inferred from a GPS-derived Strain Rate," J. Geodyn., vol. 123, hal. 49-54, 2019, doi: 10.1016/j.jog.2019. 01.004 .

[3] F. Febriani, "Seismicity around the Cimandiri fault zone, West Java, Indonesia," AIP Conf. Proc., vol. 1711, no. February 2016, 2016, doi: 10.1063/1.4941644.

[4] P. Supendi, A. D. Nugraha, N. T. Puspito, S. Widiyantoro, dan D. Daryono, "Identification of Active Faults in West Java, Indonesia, Based on Earthquake Hypocenter Determination, Relocation, and Focal Mechanism Analysis," Geosci. Lett., vol. 5, no. 1, 2018, doi: 10.1186/s40562-018-0130-y.

[5] O. M. A. Radaideh, B. Grasemann, R. Melichar, dan J. Mosar, "Detection and Analysis of Morphotectonic Features Utilizing Satellite Remote Sensing and GIS: An Example in SW Jordan," Geomorphology, vol. 275, hal. 58-79, 2016, doi: 10.1016/j.geomorph.2016.09.033.

[6] L. Han, Z. Liu, Y. Ning, dan Z. Zhao, "Extraction and Analysis of Geological Lineaments Combining a DEM and Remote Sensing Images from the Northern Baoji Loess Area," Adv. Sp. Res., vol. 62, no. 9, hal. 2480-2493, 2018, doi: 10.1016/j.asr.2018.07.030.

[7] F. D. Indrastomo, I. G. Sukadana, dan Suharji, "Identifikasi Pola Struktur Geologi Sebagai Pengontrol Sebaran Mineral Radioaktif Berdasarkan Kelurusan pada Citra Landsat- 8 di Mamuju, Sulawesi Barat," vol. 38, no. 2, hal. 7180, 2017, doi: 10.17146/eksplorium.2017.38.2. 3874.

[8] M. Nanda, S. Rizal, F. Abdullah, R. Idroes, dan N. Ismail, "Mapping Faults Distribution Based on DEM Data for Regional Spatial Plan Assessment of Sabang Municipality , Indonesia," Int. J. Geomate, vol. 19, no. 76, hal. 197-204, 2020.

[9] J. C. Escamilla-Casas dan J. E. Schulz, "Tectonic Interpretation of Topographic Lineaments in the Seacoast Region of New Hampshire, U. S. A.," Geofis. Int., vol. 55, no. 1, hal. 17-37, 2016, doi: 10.22201/igeof.00167169p.2016.55.1.1709.

[10] S. Pribadi, Afnimar, N. T. Puspito, dan G. Ibrahim, "Characteristics of EarthquakeGenerated Tsunamis in Indonesia Based on Source Parameter Analysis," J. Math. Fundam. Sci., vol. 45, no. 2, hal. 189-207, 2013, doi: 10.5614/j.math.fund.sci.2013.45.2.8.

[11] G. Sarp, "Lineament Analysis from Satellite Images, North-West of Ankara," 2005.

[12] Yuliastuti, H. Susiati, Y. Daud, dan A. S. Sastratenaya, "Identifikasi Sistem Kelurusan Di Tapak Banten Menggunakan Data Citra Satelit SPOT-5," JPEN, vol. 15, no. 1, hal. 9-16, 2013, doi: 10.17146/jpen.2013.15.1.1613.

[13] R. M. Mahbub dan H. G. Hartono, "Korelasi Sebaran Gempabumi dan Densitas Kelurusan pada Keamanan Calon Tapak PLTN Bojonegara, Banten," Kurvatek, vol. 4, no. 2, hal. 93-102, 2019, doi: 10.33579/krvtk.v4i2.1583.

[14] R. G. Thannoun, "Automatic Extraction and Geospatial Analysis of Lineaments and their Tectonic Significance in some areas of Northern Iraq using Remote Sensing Techniques and GIS," Int. J. Enhanc. Res. Sci. Technol. Eng., vol. 2, no. 2, hal. 1-11, 2013, doi: 10.13140/RG.2.2.20851. 99363.

[15] T. G. Sitharam, P. Anbazhagan, dan K. Ganesha Raj, "Use of Remote Sensing and Seismotectonic Parameters for Seismic Hazard Analysis of Bangalore," Nat. Hazards Earth Syst. Sci., vol. 6, hal. 927-939, 2006, doi: 10.5194/nhess-6-9272006.

[16] I. Haryanto, J. Hutabarat, A. Sudradjat, N. N. Ilmi, dan E. Sunardi, "Tektonik Sesar Cimandiri, Provinsi Jawa Barat,” Bull. Sci. Contrib., vol. 15, no. 3, hal. 255-274, 2017. 